\title{
Production Test of High-carbon Ferromanganese Using a Shaft Fur- nace with Coke Packed Bed Injected with Highly Oxygen Enriched Air and a Large Quantity of Pulverized Coal
}

\author{
Yasuo KAMEI, Tomio MIYAZAKI and Hideyuki YAMAOKA ${ }^{1)}$
}

R and D Task Force, JISF DIOS Process, Committee for Research and Development on the Direct Iron Ore Smelting Reduction Process, Japan Iron and Steel Federation, Kudan-minami, Chiyoda-ku, Tokyo, 102 Japan. 1) Iron and Steel Research Laboratory, Sumitomo Metal Industries, Ltd., Oaza Sunayama, Hasakimachi, Kashima-gun, Ibaraki-ken, 314-02 Japan.

(Received on April 3, 1992; accepted in final form on October 16, 1992)

\begin{abstract}
High-carbon ferromanganese has been produced by electric arc furnace in Japan. But its production cost has increased because of a speedy rising of electricity cost and Japanese ferromanganese has lost com petitiveness in the international market. So, for the purpose of decreasing its production cost, high-carbon ferromanganese production tests (production rate $=1.9-4.3 \mathrm{t} / \mathrm{d}$ ) were performed using a melting test furnace with coke packed bed injected with highly oxygen enriched air and a large quantity of pulverized coal. Moreover the operation indices of a commercial plant of $170 \mathrm{t} / \mathrm{d}$ in production capacity were estimated by heat and mass balance model, and following results were obtained.

(1) In this test, high-carbon ferromanganese of $[\mathrm{Mn}]=75 \%$ was produced stably using the coke blended with $56 \%$ non-coking coal, with coal rate of $1502 \mathrm{~kg} / \mathrm{t}$, coke rate of $1087 \mathrm{~kg} / \mathrm{t}$ and productivity of $3.11 \mathrm{t} /\left(\mathrm{d} \cdot \mathrm{m}^{3}\right)$.

(2) The total coal consumption of the commercial plant of this method is estimated to be less than that of the blast furnace in spite of higher fuel rate because a large quantity of pulverized coal is used in this process. Through these investigations, this process seems to have a prospect of being available as a ferromanganese production process instead of electric furnace method.
\end{abstract}

KEY WORDS: ferromanganese; ferroalloy; smelting reduction process; pulverized coal injection; oxygen enrichment; blast furnace; ironmaking; coke packed bed.

\section{Introduction}

High-carbon ferromanganese has been produced by electric arc furnace (EAF) in Japan. But it needs electric consumption of about $7300 \mathrm{MJ} / \mathrm{t}^{1)}$ and its production cost has increased because of a high speedy rising of electricity cost in Japan. So Japanese ferromanganese has lost competitiveness in the international market. Therefore high-carbon ferromanganese production method using no EAF has been investigated. ${ }^{2,3}$

A shaft type furnace with coke packed bed injected with highly oxygen enriched air and a large quantity of pulverized coal (PC) seems to be suitable for producing ferromanganese which is finally reduced by smelting reduction reaction. As shown in Fig. 1, the melting furnace of this process is a shaft type furnace with coke packed bed and oxygen and a large quantity of pulverized coal are injected into the furnace. The theoretical flame temperature $\left(T_{f}\right)$ can be easily increased because of the highly oxygen enriched air injection instead of the hot blast and the hot zone effective for reduction and melting in the furnace can be also easily expanded because of the pulverized coal injection in large quantities and low coke consumption. ${ }^{4)}$ Moreover, the height of furnace could be decreased because the role of indirect reduction in shaft is less important in ferromanganese production than in pig iron production as ferromanganese is finally reduced by direct reduction reaction in rather large amount. Therefore it may be possible to use low quality of coke because the coke degradation during the descent in the shaft and the load of burden to coke in the furnace

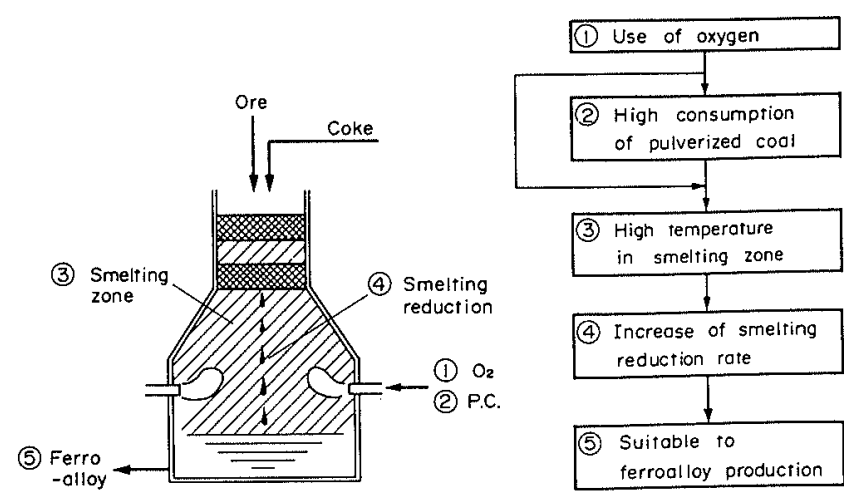

Fig. 1. Concept of this process to produce high-carbon ferromanganese. 
would decrease.

From such a background, the production tests of high-carbon ferromanganese of $[\mathrm{Mn}]=75 \%$ were performed and its smelting characteristics were clarified. And based on these results, the indices of the commercial plant of this process were studied.

\section{Outline of the Test Plant}

\subsection{Equipment}

The experimental furnace used here is shown in Fig. 2. This plant was used for the verification of the new ironmaking process which consisted of the shaft type reduction furnace and the cupola type melting furnace. ${ }^{5)}$ But Fig. 2 shows only the melting furnace because reduction furnace was not used for this test. The maximum top gas pressure is $2.96 \times 10^{5} \mathrm{~Pa}$ and the charging systems are installed at the top of the furnace, three tuyeres $^{6)}$ at the wall and a tap hole at the bottom of wall.

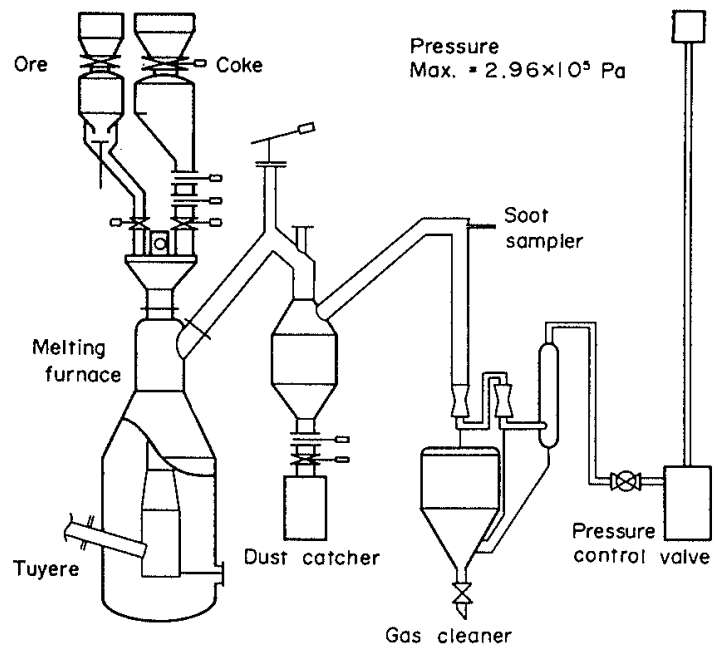

Fig. 2. Schematic diagram of the test plant.

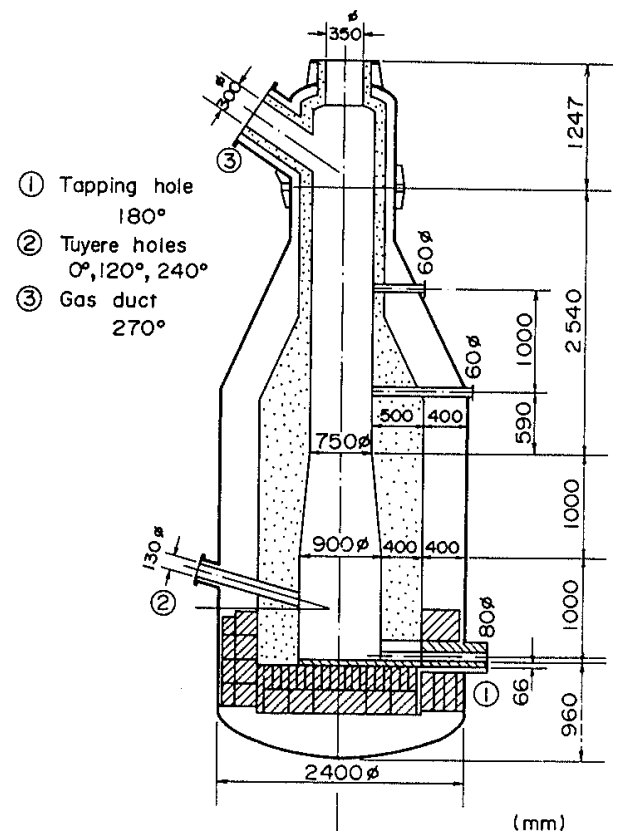

Fig. 3. Profile of the melting furnace.
The profile of the melting furnace is shown in Fig. 3 Hearth diameter is $0.9 \mathrm{~m}$, effective height (from stock line level to tuyere level) is $2.1 \mathrm{~m}$ and effective inner volume is about $1.4 \mathrm{~m}^{3}$. The values with the unit of "o" in this figure mean the circumferential direction.

\subsection{Test Condition}

Main operational indices are summarized in Table 1. Ore was used after riddled into $5-20 \mathrm{~mm}$. Coke for ferromanganese smelting electric furnace blended with $56 \%$ of non-coking coal was used after riddled into $20-50 \mathrm{~mm}$. Non-coking coal with about $34 \%$ of volatile matter crashed under 200 mesh was injected into the furnace from the tuyeres.

The ratio of pulverized coal to oxygen, the bosh gas volume $\left(V_{B}\right)$ and the top gas pressure were set about $1.0 \mathrm{~kg} / \mathrm{Nm}^{3}, 900 \mathrm{Nm}^{3} / \mathrm{h}$ and $2.48 \times 10^{5} \mathrm{~Pa}$ respectively. Here $V_{B}$ is the gas volume generated by the combustion in front of the tuyere. $T_{f}$ was controlled by nitrogen, and $T_{f}$ shown in this table is adiabatic flame temperature calculated under the assumption that the combustion products are $\mathrm{CO}, \mathrm{H}_{2}$ and $\mathrm{N}_{2}$ and the temperature of the coke entering the combustion zone is $0.75 \cdot T_{f}$ according to Ramm's method. ${ }^{7)}$ Slag basicity was controlled by limestone which was mixed with ore and coke, and $\mathrm{CaO} / \mathrm{SiO}_{2}$ of $\mathrm{Mn}$ ore and limestone mixture which is almost as same as that of coke and limestone mixture is shown in Table 1 as " $\mathrm{CaO} / \mathrm{SiO}_{2}$ of burden". The main altering test conditions are theoretical flame temperature $T_{f}$ and slag basicity $\mathrm{CaO} / \mathrm{SiO}_{2}$. Five cases were set as test conditions. Cases 1, 2, 3 were operated with $T_{f}$ of $2100,2300,2500^{\circ} \mathrm{C}$ respectively with the same basicity

Table 1. Compositions and grain sizes of ore, fuels and flux, and operation condition of the test plant.

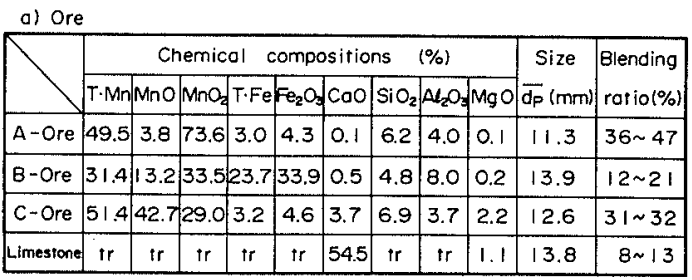

\begin{tabular}{|c|c|c|c|c|c|c|c|c|c|c|c|}
\hline & \multicolumn{2}{|c|}{ Proximote } & \multicolumn{2}{|c|}{ anolysis } & \multicolumn{2}{|c|}{ Ultimate } & \multicolumn{3}{|c|}{ onalysis (\%) } & \multirow{2}{*}{$\mid \begin{array}{c}\text { Size } \\
\overline{d p}(\mathrm{~mm})\end{array}$} & \multirow{2}{*}{$\begin{array}{l}\mathrm{DI} 30 \\
1 \%\end{array}$} \\
\hline & FC & VM & Ash & Mois & C & H & $N$ & 0 & $s$ & & \\
\hline Coke & 87.8 & 0.9 & 10.7 & 0.6 & 96.7 & 0.2 & 1.4 & 1.0 & 0.65 & 32.2 & 86.3 \\
\hline Coal & 51.1 & 35.3 & 10.4 & 3.2 & 85.9 & 4.5 & 1.8 & 7.0 & 0.71 & $\begin{array}{r}-325 m e s t \\
>90 \%\end{array}$ & - \\
\hline
\end{tabular}

\begin{tabular}{|c|c|c|}
\hline \multicolumn{2}{|c|}{ Items } & Conditions \\
\hline \multirow{8}{*}{ Blast } & Bosh gas $\left(\mathrm{Nm}^{3} / \mathrm{h}\right)$ & $898 \sim 903$ \\
\hline & $\left({ }^{\circ} \mathrm{C}\right)$ & $2093 \sim 2514$ \\
\hline & $\left(\mathrm{Nm}^{3} / \mathrm{h}\right)$ & $240 \sim 270$ \\
\hline & $\left(\mathrm{Nm}^{3} / \mathrm{h}\right)$ & $\sim 170$ \\
\hline & Steom & $\sim \quad 36$ \\
\hline & Pulverized $\operatorname{coal}(\mathrm{kg} / \mathrm{h})$ & $240 \sim 267$ \\
\hline & $\mathrm{PC} / \mathrm{O}_{2} \quad\left(\mathrm{~kg} / \mathrm{Nm}^{3}\right)$ & $\sim 1.00$ \\
\hline & Top pressure (Pa) & $2.48 \times 10^{3}$ \\
\hline $\mathrm{CoO} / \mathrm{SiO}_{2}$ & of burden & $0,97 \sim 1.5$ \\
\hline Tapping & $6 \sim 10$ & \\
\hline
\end{tabular}


of burden to investigate the $T_{\text {f }}$ influence. Cases $3,4,5$ was operated with the burden basicity of $1.7,1.4,1.2$ respectivity with $T_{f}$ of $2500^{\circ} \mathrm{C}$ to investigate the basicity influence.

\section{Operational Results}

\subsection{Transition of the Operation and Results}

The operational variations of test cases are shown in Fig. 4 using the mark of . The tapping number of each cases are 8, 8, 12, 8, 5 taps respectively. The data are mean values of several taps except the case transition periods. The mark of $O$ in the figure is the calculation result of heat and mass balance model mentioned later. The marks of white and black arrow show the response to the operation action of $T_{f}$ increase and decrease of $\mathrm{CaO} / \mathrm{SiO}_{2}$ of burden respectively. The cases 1 and 2 were operated with the ore blending ratio which was determined on the assumption that $\mathrm{Mn}$ partition equilibrium between slag and metal $\left(R_{\mathrm{Mn}}\right)$ expressed by

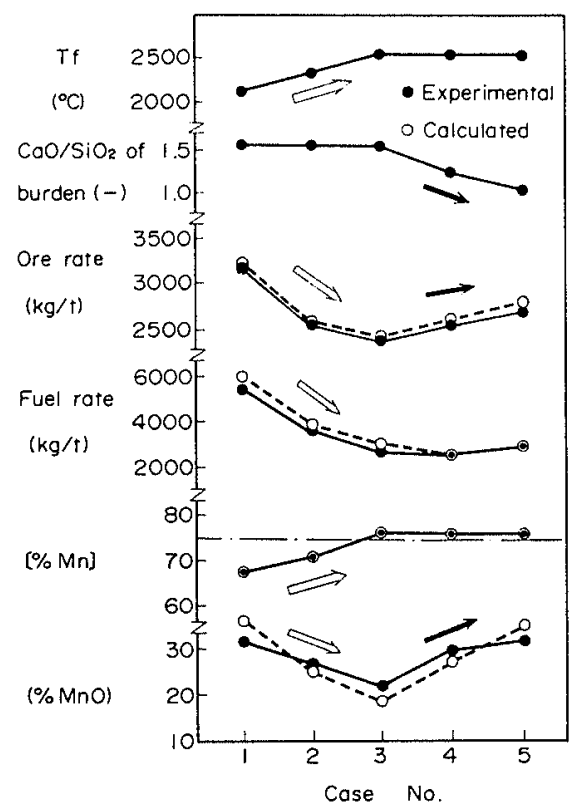

Fig. 4. Operational variations of test cases.

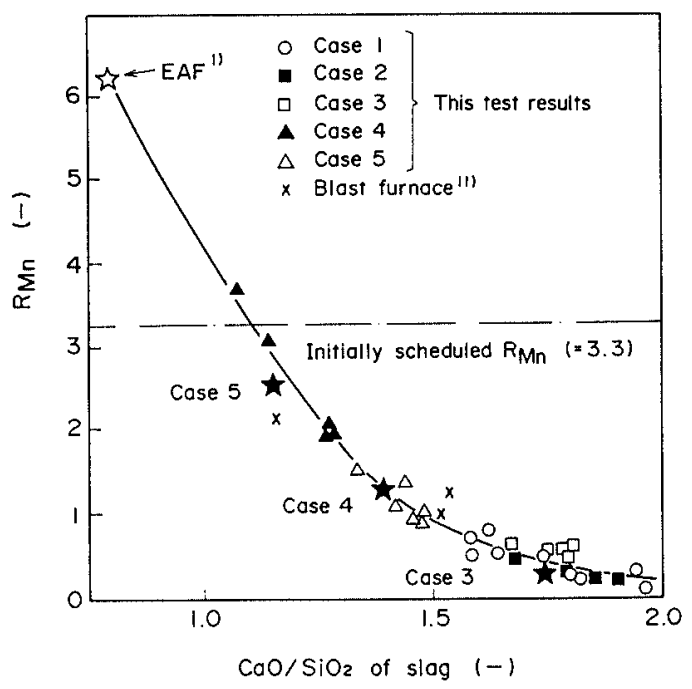

Fig. 5. Relationship between basicity $\left(N_{\mathrm{CaO}} / N_{\mathrm{SiO}_{2}}\right)$ and the degree of $\mathrm{Mn}$ partition equilibrium $\left(R_{\mathrm{Mn}}\right)$.
Eqs. (1) and (2) which was derived from the Schenck's equation ${ }^{8,9)}$ was constant at 3.3 considering the peeping test results. But [Mn] was about 67 and $70 \%$ respectively and scheduled value $75 \%$ of [Mn] was not obtained. Then the data of cases 1 and 2, and $\mathrm{EAF}^{1)}$ and blast furnace $^{11)}$ were investigated and it was clarified that $R_{\mathrm{Mn}}$ decreased remarkably according to the increase of slag basicity as shown in Fig. 5 .

$$
\begin{array}{r}
\log \left(N_{\mathrm{Mn}} / N_{\mathrm{MnO}}\right)^{*}=1.586\left(\mathrm{CaO} / \mathrm{SiO}_{2}\right)-\log P_{\mathrm{CO}}+3.17 \\
R_{\mathrm{Mn}}=\left[\frac{N_{\mathrm{Mn}}}{N_{\mathrm{MnO}}}\right]^{\text {experimental }} /\left[\frac{N_{\mathrm{Mn}}}{N_{\mathrm{MnO}}}\right]^{*} \ldots \ldots \ldots \ldots \ldots \ldots \ldots \ldots \ldots \ldots \ldots \ldots \ldots \ldots \ldots \ldots \ldots
\end{array}
$$

Therefore aimed value of $R_{\mathrm{Mn}}$ was changed as shown by the mark of $\star$ in Fig. 5 and cases $3-5$ were operated under the re-calculated operation conditions. As the result of this change, ferromanganese of $[\mathrm{Mn}]=75 \%$ was stably produced after case 3 as shown in Fig. 4 .

Examples of the results are shown in Table 2. Cases 3 and 5 in the table correspond to the conditions of high and low slag basicity respectively. From these results, it is demonstrated that high carbon ferromanganese can be produced in such a small furnace with fuel rate of $2600-2700 \mathrm{~kg} / \mathrm{t}$ using non-coking pulverized coal and low quality coke blended with $56 \%$ of non-coking coal.

As the fuel rate of this process is higher than that of $\mathrm{EAF},[\mathrm{P}]$ in the metal would increase by phosphorus in coke and coal. But its influence can be reduced by using the coal containing low concentration of phosphorus. It is considered that use of a large quantity of pulverized non-coking coal is favorable to this process in comparison with all coke operation because of increasing flexibility in selecting resources.

\subsection{Raw Material Consumption and Heat Loss}

Although the fuel rate decreased according to the $T_{f}$ increase, the decreasing degree became smaller in the higher $T_{f}$ region as shown in Fig. 4 . And in relation to

\begin{tabular}{|c|c|c|c|c|c|c|}
\hline \multicolumn{2}{|c|}{ Case of operation } & Case 1 & Cose 2 & Case 3 & Cose 4 & Case 5 \\
\hline Ore & $(\mathrm{kg} / \mathrm{l})$ & 3219 & 2546 & 2421 & 2567 & 2678 \\
\hline \multirow{6}{*}{ Blast } & $\left(\mathrm{Nm}^{3} / \mathrm{h}\right)$ & 241 & 255 & 272 & 270 & 271 \\
\hline & $\left(\mathrm{Nm}^{3} / \mathrm{n}\right)$ & 151 & 151 & 170 & 170 & 170 \\
\hline & $(\mathrm{kg} / \mathrm{h})$ & 36 & 21 & 0 & 0 & 0 \\
\hline & $(\mathrm{kg} / \mathrm{h})$ & 237 & 256 & 267 & 263 & 266 \\
\hline & $\left|{ }^{\circ} \mathrm{C}\right|$ & 2109 & 2292 & 2509 & 2513 & 2508 \\
\hline & Bosh gos $\left(\mathrm{Nm}^{3} / \mathrm{h}\right)$ & 897 & 899 & 908 & 902 & 903 \\
\hline \multirow{3}{*}{ Top gas } & Temp. & 650 & 694 & 722 & 720 & 729 \\
\hline & \begin{tabular}{|l|} 
Pressure \\
\end{tabular} & $2.48 \times 10^{3}$ & $2.48 \times 10^{5}$ & $2.48 \times 10^{5}$ & $2.48 \times 10^{5}$ & $2.48 \times 10^{5}$ \\
\hline & Dust conc $\left(\mathrm{g} / \mathrm{Nm}^{3}\right)$ & 35.8 & 47.8 & 69.7 & 69.8 & 71.9 \\
\hline \multirow{3}{*}{ Fuel rore } & Coke $\quad(\mathrm{kg} / \mathrm{l})$ & 2580 & 1692 & 1087 & 1099 & 1117 \\
\hline & $(\mathrm{kg} / \mathrm{t})$ & 2964 & 2032 & 1502 & 1514 & 1598 \\
\hline & $\{\mathrm{kg} / \mathrm{t})$ & 5544 & 3724 & 2589 & 2613 & $27 \mid 5$ \\
\hline \multirow{2}{*}{ Production } & Production $(1 / d)$ & 1.91 & 3.03 & 4.26 & 4.17 & 3.99 \\
\hline & Productivity (s/d-m & 1.39 & 2.21 & 3.11 & 3.04 & 2.91 \\
\hline \multirow{10}{*}{ Product } & Temp. of hot metal & 1395 & 1423 & 1380 & 1369 & 1377 \\
\hline & $\begin{array}{|ll|}{[\% \mathrm{Mn}]} & (\%)\end{array}$ & 66.5 & 71.3 & 76.2 & 75.1 & 75.1 \\
\hline & $6 \% \circ]$ & 6.6 & 6.8 & 6.9 & 6.8 & 6.6 \\
\hline & $(\% 5 i)$ & 0.13 & 0.23 & 0.17 & 0.37 & 0.22 \\
\hline & {$\left[\begin{array}{ll}\% & P\end{array}\right]$} & 0.44 & 0.35 & 0.31 & 0.32 & 0.34 \\
\hline & $(\% \mathrm{MnO})$ & 32.1 & 26.4 & 23.3 & 30.0 & 32.1 \\
\hline & $\left(\% \mathrm{Al}_{2} \mathrm{O}_{3}\right) \quad(\%)$ & 15.0 & 16.7 & 17.8 & 15.7 & 15.8 \\
\hline & $\mathrm{Slag} \mathrm{CoO} / \mathrm{SiO}_{2}(-1$ & 1.77 & 1.79 & 1.70 & 1.40 & 1.29 \\
\hline & $\begin{array}{|ll|}\text { NMn } / \text { NMnO } & (-1) \\
\end{array}$ & 1.82 & 2.33 & 2.73 & 2.11 & 1.94 \\
\hline & Mn yield & 84.4 & 87.3 & 84.9 & 95.6 & 79.3 \\
\hline
\end{tabular}

Table 2. Operation results of the test plant. 
the fuel rate, bosh gas rate $V_{R}$ decreased according to $T_{f}$ increase and came to about $5115 \mathrm{Nm}^{3} / \mathrm{t}$ (case 3) at $2500^{\circ} \mathrm{C}$ of $T_{f}$.

As shown in Fig. 4, the ore rate of case 2 decreased in spite of the same blending ratio as that of case 1 because $\mathrm{Mn}$ oxide reduction was promoted and metal amount produced per 1 ton of ore was increased as the result of $T_{f}$ increase in case 2 .

Although $T_{f}$ was increased, the top gas temperature did not increased remarkably, and the heat input increase caused by $T_{f}$ increase worked to the Mn smelting effectively and lead to the increase in production rate. The amount of heat loss obtained from mass and heat balance remained almost constant about $870 \mathrm{MJ} / \mathrm{h}$ and did not increased. So heat loss rate $(\mathrm{MJ} / \mathrm{t})$ decreased resulting in fuel rate and $V_{R}$ decrease.

\section{Discussion}

\subsection{Mn Partition between Metal and Slag}

Although Mn partition between metal ans slag has been already investigated, ${ }^{12)}$ Eq. (1) was used in this investigation as a first step because Mn concentration in ferromanganese is much higher than that of pig iron. But as the results of this test, it was clarified that $\mathrm{Mn}$ partition ratio between metal and slag depends not only on the slag basicity as expressed by Eq. (1) but also on the temperature and the dependency itself on the slag basicity should be restudied.

\section{(1) Influence of the $\mathrm{CaO} / \mathrm{SiO}_{2}$ of Slag}

Figure 6 shows the results of classification of the data by $T_{f}$ and the coefficient of 0.382 is obtained about the relationship between $\mathrm{Mn}$ partition ratio and $\mathrm{CaO} / \mathrm{SiO}_{2}$ under the condition of constant $T_{f}$. Therefore Eq. (1) is expressed as follows.

$$
\frac{\partial \log \left(N_{\mathrm{Mn}} / N_{\mathrm{MnO}}\right)}{\partial\left(\mathrm{CaO} / \mathrm{SiO}_{2}\right)}=0.382
$$

\section{(2) Influence of Temperature}

If slag temperature is accepted as the temperature index, and if whole data is accepted as one group without classification by $T_{f}$ and $\mathrm{CaO} / \mathrm{SiO}_{2}$ the dependency of

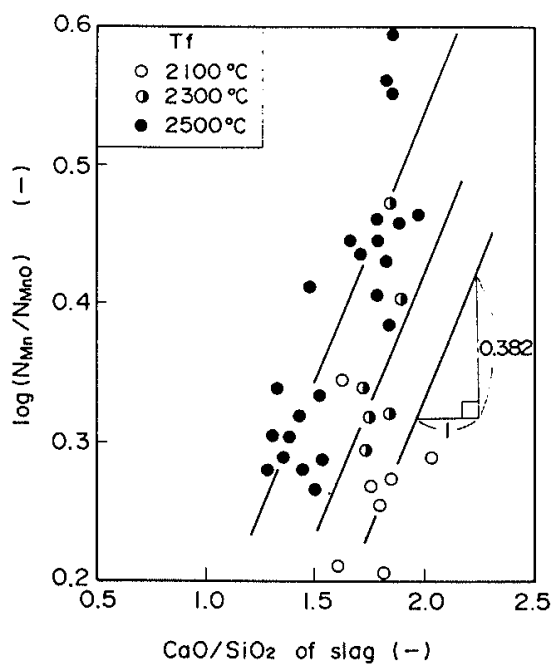

Fig. 6. Influence of slag $\mathrm{CaO} / \mathrm{SiO}_{2}$ on $M_{\mathrm{Mn}} / N_{\mathrm{MnO}}$. whole data on slag temperature shows a similarity to that of the equilibrium constant ${ }^{13)}$ as shown in Fig. 7. But the Mn partition ratio shown by the mark of $\mathbf{A}$ $\left(\mathrm{CaO} / \mathrm{SiO}_{2}=1.3-1.5\right)$ is higher than that shown by $\mathrm{O}$ $\left(\mathrm{CaO} / \mathrm{SiO}_{2}=1.7-1.9\right)$ and this fact is inconsistent with the $\mathrm{CaO} / \mathrm{SiO}_{2}$ dependency expressed by Eq. (3). On the other hand, Mn partition ratio depends also on the $T_{f}$ as shown in Fig. 8 with the relationship expressed by Eq. (4) and this relationship could be classified by $\mathrm{CaO} / \mathrm{SiO}_{2}$ in this case. It is considered as follows about the reason why $T_{f}$ has an effect on the Mn partition ratio. The heat exchange is improved by the $T_{f}$ increase because reduction reaction of $\mathrm{MnO}$ is endothermic and this results in the promotion of $\mathrm{Mn}$ oxide reduction.

$$
\frac{\partial \log \left(N_{\mathrm{Mn}} / N_{\mathrm{MnO}}\right)}{\partial T_{f}}=5.43 \times 10^{-4}
$$

And considering the relationship expressed by Eqs. (3) and (4), the inconsistency about the dependency on $\mathrm{CaO} / \mathrm{SiO}_{2}$ in Fig. 7 can be explained by the inclusion of the $T_{f}$ influence. That is, if the data in Fig. 7 are classified by $T_{f}$ and $\mathrm{CaO} / \mathrm{SiO}_{2}$ as shown by full line, the dependency on slag temperature expressed by Eq. (5) is

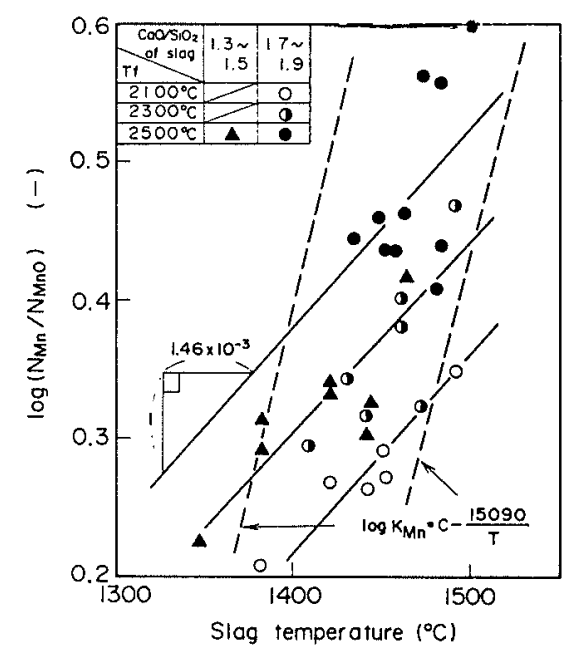

Fig. 7. Influence of slag temperature on the $\mathrm{Mn}$ partition ratio between metal and slag.

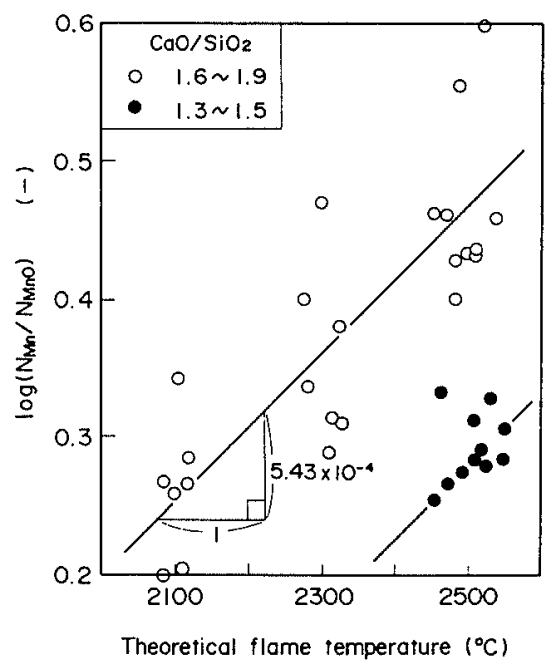

Fig. 8. Influence of $T_{f}$ on the $\mathrm{Mn}$ partition ratio between metal and slag. 


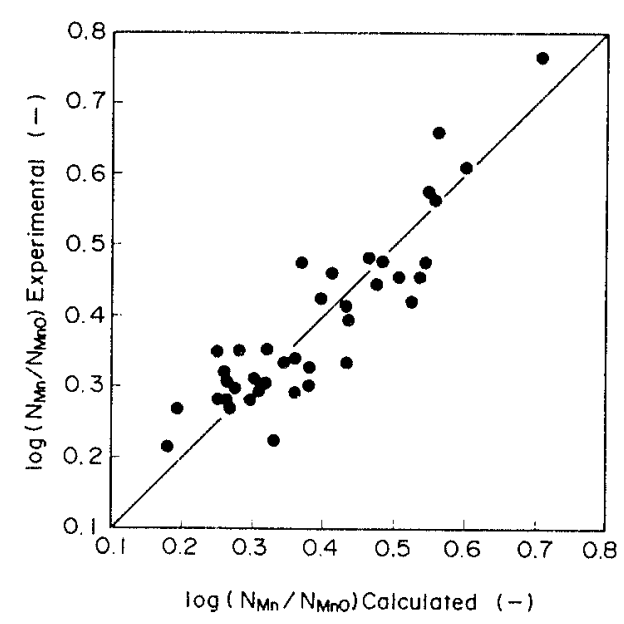

Fig. 9. Comparison of $\mathrm{Mn}$ partition ratio between test plant results and calculation results by Eq. (7).

obtained and the relationship in Fig. 7 can be expressed consistently.

$$
\frac{\partial \log \left(N_{\mathrm{Mn}} / N_{\mathrm{MnO}}\right)}{\partial T_{\text {siag }}}=1.46 \times 10^{-3}
$$

Considering Eqs. (3)-(5), and assuming that $\mathrm{CaO} / \mathrm{SiO}_{2}$, $T_{f}, T_{\text {slag }}$, are independent variable, the relationship between $\log \left(N_{\mathrm{Mn}} / N_{\mathrm{MnO}}\right)$ and $\alpha$ shown by Eq. (6) was investigated, and straight line relationship was obtained which gives Eq. (7). The relationship between " $\log \left(N_{\mathrm{Mn}} / N_{\text {MnO }}\right)_{\text {experimental }}$ obtained from this test and

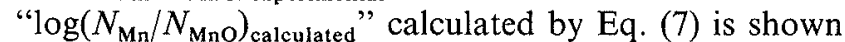
in Fig. 9. Equation (7) seems to be reasonable from this figure.

$$
\begin{aligned}
\alpha= & 0.382\left(\mathrm{CaO} / \mathrm{SiO}_{2}\right)+5.43 \times 10^{-4} T_{f} \\
& +1.46 \times 10^{-3} T_{\text {slag }}-\log P_{\mathrm{CO}} \\
\log \frac{N_{\mathrm{Mn}}}{N_{\mathrm{MnO}}}= & 0.382 \frac{\mathrm{CaO}}{\mathrm{SiO}_{2}}+5.43 \times 10^{-4} T_{f} \\
& +1.46 \times 10^{-3} T_{\text {slag }}-\log P_{\mathrm{CO}}+1.545
\end{aligned}
$$

\subsection{Yield of $\mathrm{Mn}$ and $\mathrm{SiO}_{2}$}

The relationship between $\mathrm{Mn}$ yield and $V_{R}$ was not obtained. It is considered that the effect of $T_{f}$ increase to increase the dust concentration is canceled by the effect of $V_{R}$ decrease to decrease the dust amount. Mn and $\mathrm{SiO}_{2}$ yield was analyzed by using the following relationship:

\section{amount of loss $\propto$ dust amount}

$$
\text { ( = dust concentration } \times \text { gas volume) }
$$

(1) Relationship between $\mathrm{Mn}$ and $\mathrm{SiO}_{2}$ Loss and Dust Amount

The relationship between $\mathrm{Mn}$ and $\mathrm{SiO}_{2}$ loss and dust amount is shown in Fig. 10. Here, $\mathrm{Mn}$ and $\mathrm{SiO}_{2}$ loss are the difference between the input amount in the burden and output amount in metal and slag. Total amount of dust is calculated by Eq. (8) as the summation of the amount of dust caught and not caught at dust catcher.

$$
W_{\text {dust }}=W_{d . d}+10^{-3} W_{s . d} \times V_{g}
$$

\begin{tabular}{|c|c|c|c|c|c|c|c|c|}
\hline mesh & +32 & $\begin{array}{l}32 \\
-60 \\
\end{array}$ & $\begin{array}{l}60 \\
-100 \\
\end{array}$ & $\begin{array}{l}100 \\
-150 \\
\end{array}$ & $\begin{array}{l}150 \\
-200 \\
\end{array}$ & 200 & -325 & $\overline{\mathrm{d}_{p}}(\mu \mathrm{m})$ \\
\hline Dust cotcher & 2.0 & 8.3 & 7.4 & 5.6 & 3.7 & 5.6 & 67.4 & 31.0 \\
\hline Outlet of D.C. & ir & Ir & 0.02 & 0.04 & 0.08 & 0.35 & 99.51 & 22.1 \\
\hline Toral & 1.2 & 5.0 & 4.4 & 3.3 & 2.3 & 3.4 & 80.4 & 27.4 \\
\hline
\end{tabular}

From the ratio of loss amount to dust amount, $\mathrm{Mn}$ and
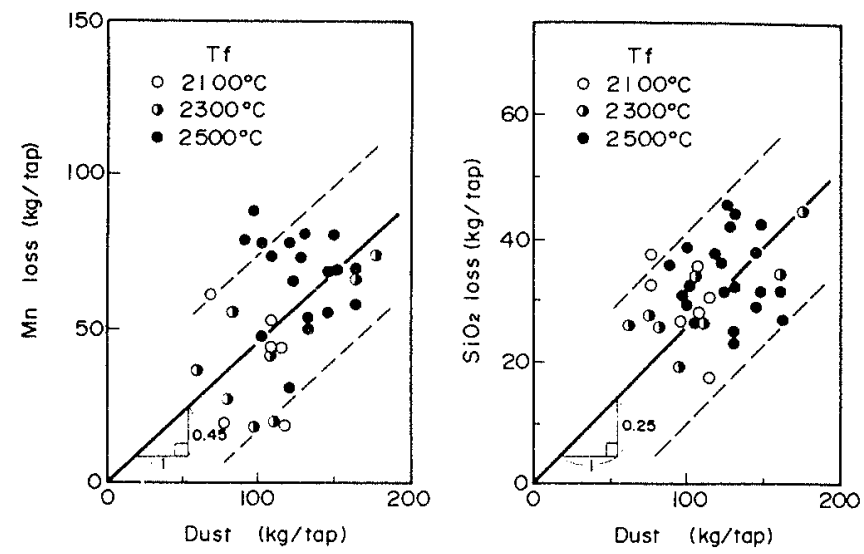

Fig. 10. Relationship between $\mathrm{Mn}$-loss, $\mathrm{SiO}_{2}$-loss and dust.

Table 3. Properties of dust in the top gas.

b) Chemical composition (\%)
\begin{tabular}{|c|c|c|c|c|c|c|c|c|c|c|}
\hline & T.Mr & SiOz & 41203 & COO & Mgo & T.Fe & NazO & $K_{2} \mathrm{O}$ & T.S & T.C \\
\hline Oust cotcher & 30.1 & 11.3 & 6.8 & 6.4 & 0.9 & 2.8 & 0.5 & 1.9 & 0.9 & 26.4 \\
\hline Outlet of D.C & 30.8 & 15.1 & 7.9 & 6.4 & 1.4 & 1.1 & 1.1 & 3.8 & 1.7 & 14.3 \\
\hline Total & 30.4 & 12.8 & 7.2 & 6.4 & 1.1 & 2.1 & 0.7 & 2.7 & 1.2 & 21.5 \\
\hline
\end{tabular}

$\mathrm{SiO}_{2}$ concentration in the dust were decided to be 45 and $25 \%$ respectively as mean values of the region shown by broken line. On the other hand, the $\mathrm{Mn}$ and $\mathrm{SiO}_{2}$ concentration in the dust of this test were 30 and $13 \%$ respectively as shown in Table 3. Although there are slight differences between the value from Fig. 10 and Table 3, the former was used in the mass and energy balance model of ferromanganese production because of the difficulty of measuring the dust amount precisely.

(2) Influence Factor on the Dust concentration

It can be considered that $T_{f}$ and $T_{\text {slag }}$ as a temperature index of lower part of the furnace are factors of dust generation and $T_{g}$ is a dust trap factor of packed bed. As a result of the relationship study between dust concentration and above factors, the relationship shown in Fig. 11 was found and expressed by Eq. (9).

$$
D=0.0875 T_{f}+0.1 T_{g}-214
$$

$\mathrm{Mn}$ and $\mathrm{SiO}_{2}$ loss can be expressed by following equation using the above mentioned results.

$$
\begin{gathered}
D_{\mathrm{Mn}}=\frac{0.45}{1000} D \cdot V_{R} \\
D_{\mathrm{SiO}_{2}}=\frac{0.25}{1000} D \cdot V_{R}
\end{gathered}
$$

(3) Possibility of Mn Vaporization Loss

Since boiling temperature of $\mathrm{Mn}\left(2050^{\circ} \mathrm{C}\right)$ is lower than $T_{f}$ and dust shape looks like sphere as shown in Fig. 12, Mn vaporization can be considered to have high 


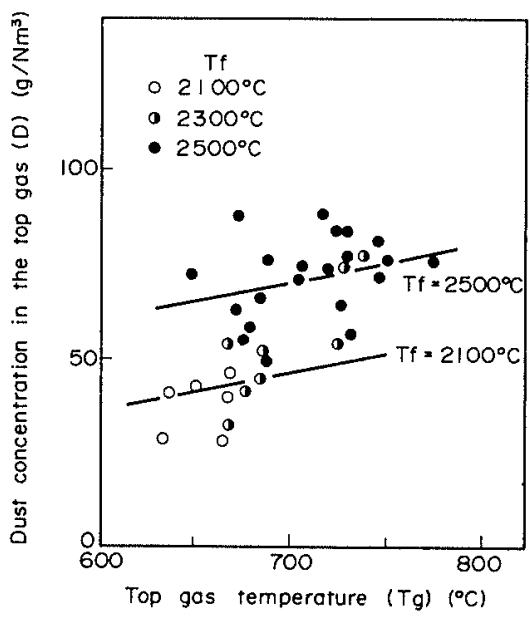

Fig. 11. Influence of top gas temperature and $T_{f}$ on the dust concentration in the top gas.

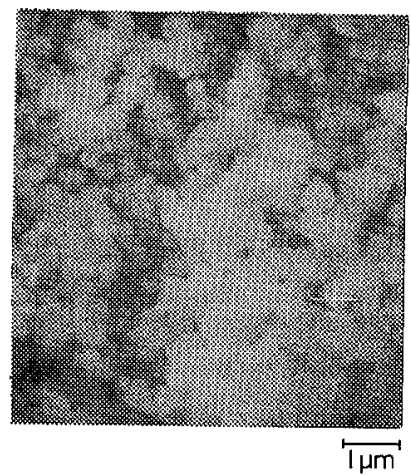

Fig. 12. Photograph of the dust sampled from the off gas.

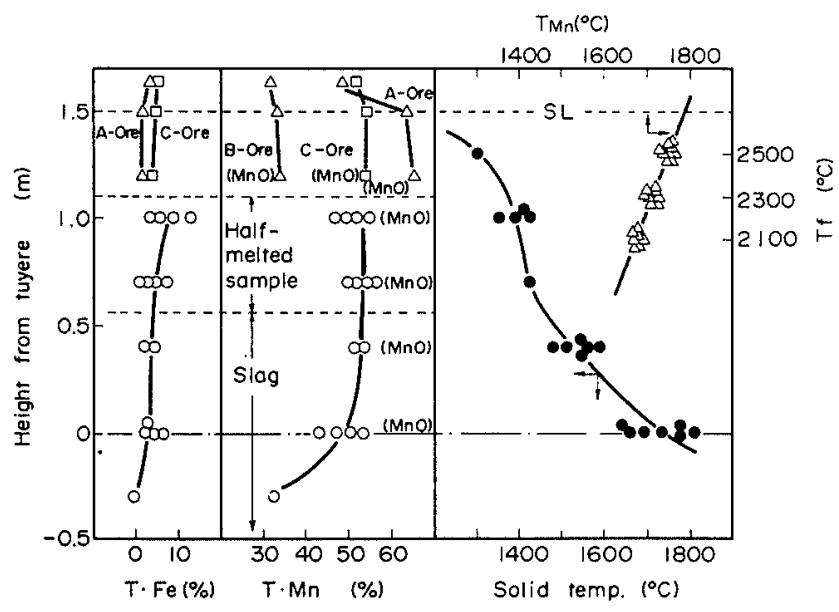

Fig. 13. Dissection results of the melting furnace.

potential for Mn loss. ${ }^{3)}$

The furnace was quenched by nitrogen blown through the tuyeres and the intersection study was performed after the smelting test. Its results are shown in Fig. 13. Here, the temperature in the furnace is estimated through the analysis of the crystallite size of sampled coke in the direction of (002). Mn ore is heated rapidly to about $1300^{\circ} \mathrm{C}$ in the upper part of the furnace and $\mathrm{Mn}$ oxide is reduced to $\mathrm{MnO}$ there, but final reduction to metallic $\mathrm{Mn}$ occurrs in the smelting zone higher than $1500^{\circ} \mathrm{C}$.

Figure 13 also shows the relationship between $T_{f}$ and the temperature $T_{\mathrm{Mn}}$ which is calculated by Eqs. (12) and
(13), where $W_{\mathrm{Mn}}$ is $\mathrm{Mn}$ loss calculated as the difference between $\mathrm{Mn}$ amount in burden and in metal and slag, and $a_{\mathrm{Mn}}$ is calculated according to Schenck's method. ${ }^{8)}$ Here it is assumed that Mn loss is caused only by $\mathrm{Mn}$ vaporization and fume dust originating from $\mathrm{Mn}$ vapor is not trapped in the furnace. Although these assumption may be have some problems, ${ }^{3)}$ it is overlooked here because qualitative effect of $T_{f}$ on Mn loss is intended to be investigated.

$$
\begin{aligned}
& P_{\mathrm{Mn}}=\frac{22.4 \cdot W_{\mathrm{Mn}} \cdot P_{\mathrm{top}}}{54.94 \cdot V_{B}} . . \\
& \mathrm{Mn}(\mathrm{l})=\mathrm{Mn}(\mathrm{g}) \\
& \Delta G^{\circ}=235768-197.0 \cdot T_{\mathrm{Mn}}{ }^{10)} \\
&=-R \cdot T_{\mathrm{Mn}} \cdot \ln \left(P_{\mathrm{Mn}} / a_{\mathrm{Mn}}\right)
\end{aligned}
$$

Figure 13 shows that $T_{\mathrm{Mn}}$ corresponds to the temperature near the tuyere level where $\mathrm{Mn}$ is finally reduced. And the relationship between the $T_{\mathrm{Mn}}$ and hot metal temperature is not found but the straight line relationship between $T_{\mathrm{Mn}}$ and $T_{f}$ is obtained. That is, $T_{\mathrm{Mn}}$ increased according to the $T_{f}$ increase. Therefore if $T_{f}$ is increased, the temperature of tuyere level zone also increase and it results in the increase in $\mathrm{Mn}$ vapor pressure leading to Mn loss increase.

\subsection{Mass and Energy Balance Model of Smelting Mn Ore}

Mass and heat balance model of smelting $\mathrm{Mn}$ ore was made taking the above mentioned results into account. In this model, it is assumed that $\mathrm{Mn}$ oxide is reduced to $\mathrm{MnO}$ by $\mathrm{CO}$ at the temperature below $1000^{\circ} \mathrm{C}$, and thereafter $\mathrm{MnO}$ is reduced to $\mathrm{Mn}$ by $\mathrm{C}$. Blast condition is calculated if $T_{f}, \mathrm{PC} / \mathrm{O}_{2}$, steam rate is given. Its estimation results for cases 1 to 5 are shown in Fig. 4 using the mark of $\bigcirc$ compared with this test's results (-), and its accuracy is acceptable.

\subsection{Estimation of the Indices of Commercial Plant with Production Capacity of $170 \mathrm{t} / \mathrm{d}$}

The indices of commercial plant with production capacity of $170 \mathrm{t} / \mathrm{d}$ producing ferromanganese were estimated by using the above mentioned model. Heat loss and the furnace profile of this process and blast furnace $\mathrm{BF}^{11)}$ which produced ferromanganese were compared and set as shown in Table 4, and the indices were calculated as shown in Table 5.

\section{(1) Profile of the Furnace}

The productivity per unit furnace volume obtained from this test is $3.11 \mathrm{t} /\left(\mathrm{d} \cdot \mathrm{m}^{3}\right)$ and much more than that of BF. But it can be considered that productivity per unit furnace volume of this process, which is an index of heat transfer rate $\left(\mathrm{J} /\left(\mathrm{m}^{3} \cdot \mathrm{h}\right)\right)$ and reaction rate $(\mathrm{kmol} /$ $\left.\left(\mathrm{m}^{3} \cdot \mathrm{h}\right)\right)$, can be maintained in the large scale furnace because the coke and ore particle size used in this test are $20-50$ and $5-20 \mathrm{~mm}$ respectively which are not different from those of BF. Therefore the productivity of the commercial plant was fixed at $3.11 \mathrm{t} /\left(\mathrm{d} \cdot \mathrm{m}^{3}\right)$ and furnace volume was calculated to be $55 \mathrm{~m}^{3}$ from the productivity and production capacity.

On the other hand, the productivity per unit of hearth 
Table 4. Profile comparison between the blast furnace and this process.

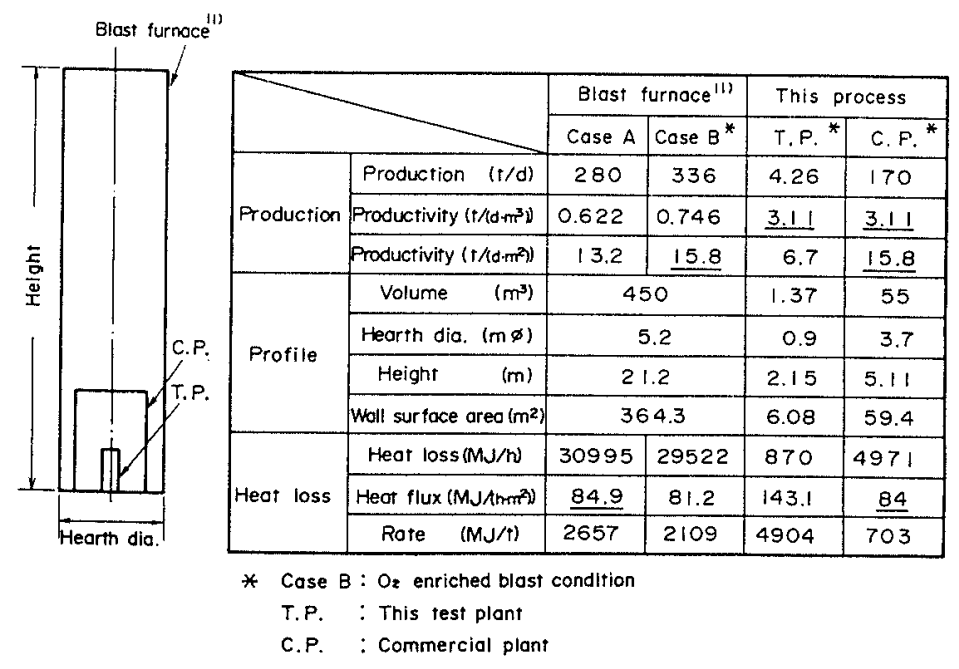

Table 5. Rate comparison between the blast furnace and this process.

\begin{tabular}{|c|c|c|c|c|c|c|}
\hline & \multirow{2}{*}{\multicolumn{2}{|c|}{ Blost Furnace ${ }^{\prime \prime \prime}$}} & \multicolumn{3}{|c|}{ This Process } \\
\hline & & & & \multirow{2}{*}{\begin{tabular}{|c|} 
Test Plant \\
Basic \\
\end{tabular}} & \multicolumn{2}{|c|}{ Commercial Plont } \\
\hline & & Cose A & Cose $B^{*}$ & & Acid & Basic \\
\hline Material & Ore rate & 2035 & 1968 & 2421 & 2497 & 1981 \\
\hline \multirow{3}{*}{ Fuel } & Coke rate $(\mathrm{kg} / \mathrm{t})$ & 1420 & 1374 & 1087 & 664 & 711 \\
\hline & PC rate $(\mathrm{kg} / \mathrm{t})$ & 0 & 0 & 1502 & 1063 & 826 \\
\hline & Fuel rote $(\mathrm{kg} / \mathrm{t})$ & 1420 & 1374 & 2589 & 1727 & 1537 \\
\hline \multicolumn{2}{|c|}{ Total coat consumption $(\mathrm{kg} / \mathrm{t})$} & 2190 & 2120 & 3179 & 2087 & 1923 \\
\hline \multirow{7}{*}{ Blost } & Air $\quad\left(\mathrm{Nm}^{3} / t\right)$ & Hot 4053 & Hot 3153 & 0 & 0 & Cold 575 \\
\hline & $\left(\mathrm{Nm}^{3} / \mathrm{T}\right)$ & 0 & 154 & 1530 & 886 & 705 \\
\hline & $\left(\mathrm{Nm}^{3} / \mathrm{t}\right)$ & 0 & 0 & 926 & 0 & 0 \\
\hline & Steam & 0 & 0 & 0 & 66 & 0 \\
\hline & $\mathrm{Tf} \quad\left({ }^{\circ} \mathrm{C}\right)$ & 2190 & 2420 & 2509 & 2500 & 2500 \\
\hline & Bosh gos $\left(\mathrm{Nm}^{3} / \mathrm{t}\right)$ & 4902 & 3963 & 5115 & 2800 & 2766 \\
\hline & Top pressure $(\mathrm{Po})$ & $2.04 \times 10^{5}$ & $2.08 \times 10^{5}$ & $2.48 \times 10^{5}$ & $2.48 \times 10^{3}$ & $2.48 \times 10^{8}$ \\
\hline \multirow{5}{*}{ Product } & Temp of metal $\left({ }^{\circ} \mathrm{C}\right)$ & 1450 & 1470 & 1380 & 1400 & 1450 \\
\hline & {$[\% \mathrm{Mn}] \quad(\%)$} & 76.4 & 76.6 & 76.2 & 74.5 & 74.5 \\
\hline & $(\%$ MnO $) \quad(\%)$ & 12.0 & 11.1 & 23.3 & 44.5 & 13.8 \\
\hline & $\mathrm{Slog} \mathrm{CaO} / \mathrm{SiO}_{2}(-)$ & 1.54 & 1.56 & 1.70 & 0.77 & 1.85 \\
\hline & Mn yield $\quad(\%)$ & 89.5 & 90.8 & 84.9 & 91.6 & 92.2 \\
\hline
\end{tabular}

area obtained in this test is $6.7 \mathrm{t} /\left(\mathrm{d} \cdot \mathrm{m}^{2}\right)$ and about half of that of BF. But it was assumed to be $15.8 \mathrm{t} /\left(\mathrm{d} \cdot \mathrm{m}^{2}\right)$ of $\mathrm{BF}$ because bosh gas velocity of this test is smaller than that of $\mathrm{BF}$ and there are plenty of room for gas velocity. Therefore hearth diameter of the commercial plant was determined to be $3.7 \mathrm{~m} \phi$.

\section{(2) Heat Loss}

The heat loss of Thyssen's blast furnace is 29522 $30995 \mathrm{MJ} / \mathrm{h}$ which corresponds to about $84 \mathrm{MJ} /\left(\mathrm{m}^{2} \cdot \mathrm{h}\right)$ of the heat flux in wall. On the other hand, the heat flux of this test plant is $143 \mathrm{MJ} /\left(\mathrm{m}^{2} \cdot \mathrm{h}\right)$ and slightly higher than that of the blast furnace. In the case of commercial plant, $84 \mathrm{MJ} /\left(\mathrm{m}^{2} \cdot \mathrm{h}\right)$ was adopted becuase heat flux of this process would decrease according to the scale up. As the result of this, heat loss of commercial plant become to $4971 \mathrm{MJ} / \mathrm{h}$.

(3) Indices Comparison between This Process and the Blast Furnace

The indices was estimated for following two operation conditions as is performed in EAF process, i.e. acid operation: $\mathrm{MnO}$ is left in slag in rather high level to be used as the material for producing silicomanganese, basic operation: $\mathrm{MnO}$ is reduced as much as possible and slag is abandoned. "Basic" and "Acid" in Table 5 correspond to "basic operation" and "acid operation" respectively. The estimation results showed that high $T_{f}$ was favorable in both operational conditions from a viewpoint of fuel rate and ore rate. Moreover it was found by model estimation that partial pressure decrease of $\mathrm{CO}$ by air addition to oxygen blowing was effective to reduce $\mathrm{MnO}$ further. So the operational conditions shown in Table 5 were chosen as appropriate ones and various indices were estimated as shown in the table.

Although this process is equivalent to the blast furnace process from a viewpoint of $\mathrm{Mn}$ yield and ore rate, this process is superior than blast furnace from a viewpoint of fuel source because non-coking pulverized coal and low quality coke containing $56 \%$ of non-coking coal can be used in this process. Moreover coal consumption of this process can be reduced less than that of the blast furnace because a plenty of the pulverized coal is used in this process. Through these investigations, this process has been confirmed to be useful one as a ferromanganese production process instead of electric furnace method and blast furnace method.

\section{Conclusion}

Experiments of high-carbon ferromanganese production were performed using an experimental melting furance with coke packed bed injected with oxygen and pulverized coal and following results wre obtained.

(1) In the experimental plant, high-carbon ferromanganese of $[\mathrm{Mn}]=75 \%$ was produced stably, using the coke blended with $56 \%$ non-coking coal, with coal rate of $1502 \mathrm{~kg} / \mathrm{t}$, coke rate of $1087 \mathrm{~kg} / \mathrm{t}$ and productivity of $3.11 \mathrm{t} /\left(\mathrm{d} \cdot \mathrm{m}^{3}\right)$.

(2) On the basis of the results obtained by this tests and blast furnace operation, the indices of a commercial plant of $170 \mathrm{t} / \mathrm{d}$ in production capacity was estimated. Although the fuel rate is higher than that of blast furnace method but the total coal consumption is less than that of blast furnace because a large quantity of pulverized 
coal is used in this process. Through these investigations, this process has been confirmed to be useful one as a ferromanganese production process instead of EAF method and BF method.

\section{Nomenclature}

$a_{\mathrm{Mn}}:$ activity of $\mathrm{Mn}$ in ferromanganese (-)

$\mathrm{CaO}$ : weight percent of $\mathrm{CaO}$ in slag (wt\%)

$D:$ dust concentration in the raw gas $\left(\mathrm{g} / \mathrm{Nm}^{3}\right)$

$D_{\mathrm{Mn}}: \quad \mathrm{Mn}$ loss $(\mathrm{kg} / \mathrm{t})$

$D_{\mathrm{SiO}_{2}}: \quad \mathrm{SiO}_{2}$ loss $(\mathrm{kg} / \mathrm{t})$

$N_{i}$ : molar fraction of $i$ component $(-)$

$P_{i}: \quad$ partial pressure of $i$ component (Pa)

$P_{\text {top }}:$ top gas pressure $(\mathrm{Pa})$

$R$ : gas constant $(8.314 \mathrm{~J} / \mathrm{mol} \cdot \mathrm{K})$

$R_{\mathrm{Mn}}$ : degree of Mn partition equilibrium between metal and slag (-)

$\mathrm{SiO}_{2}$ : weight percent of $\mathrm{SiO}_{2}$ in slag (wt \%)

$T_{g}$ : top gas temperature $\left({ }^{\circ} \mathrm{C}\right)$

$T_{\text {slag }}:$ slag temperature $\left({ }^{\circ} \mathrm{C}\right)$

$V_{B}:$ bosh gas volume $\left(\mathrm{Nm}^{3} / \mathrm{h}\right)$

$V_{g}:$ off gas volume $\left(\mathrm{Nm}^{3} / \mathrm{tap}\right)$

$V_{R}:$ bosh gas rate $\left(\mathrm{Nm}^{3} / \mathrm{t}\right)$

$W_{\text {dust }}:$ dust amount $(\mathrm{kg} / \mathrm{tap})$

$W_{d . d}:$ dust amount trapped by dust catcher $(\mathrm{kg} / \mathrm{tap})$

$W_{s . d}$ : dust concentration in the gas after dust catcher $\left(\mathrm{g} / \mathrm{Nm}^{3}\right)$
$W_{\mathrm{Mn}}:$ Mn loss $(\mathrm{kg} / \mathrm{h})$

$\Delta G^{\circ}:$ Gibbs free energy $(\mathrm{J})$

\section{REFERENCES}

1) W. Naruse: Proc. the 1st Int. Ferroalloys Cong. (INFACON 74), South African Inst. Mining Metall., Johannesburg, (1975), 69.

2) T. Morimoto, M. Yoshimoto, H. Takahashi, T. Hamada, N. Fukushima and S. Sakurai: Kawasaki Steel Tech. Rep., 17 (1987), 1.

3) H. Kokubu, T. Inatani, T. Nozaki, H. Fujimori, M. Masukawa and Y. Omori: Tetsu-to-Hagané, 75 (1989), 602.

4) H. Yamaoka and Y. Kamei: ISIJ Int., 32 (1992), 701.

5) T. Miyazaki, H. Yamaoka, Y. Kamei and F. Nakamura: Trans. Iron Steel Inst. Jpn., 27 (1987), 615.

6) H. Yamaoka and Y. Kamei: ISIJ Int., 32 (1992), 709.

7) A. N. Ramm: Contemporary Problems of Metallurgy, ed. by Samarin (translated from Russian), Consultants Bureau, New York, (1960), 51.

8) H. Schenck and F. Neumann: Arch. Eisenhüttenwes., 30 (1959), 705 .

9) H. Schenck, M. G. Frohberg and T. G. Gammal: Arch. Eisenhüttenwes., 31 (1960), 567.

10) E. T. Turkdogan: Physical Chemistry of High Temperature Technology, Academic Press, New York, (1980), 15.

11) W. Altpeter: Dissertation zur Erlangung des Grades eines Doktor-Ingenieurs, genehmigt von der Fakultät für Bergbau und Hüttenwesen der Technischen Hochschule Clausthal, Tag der mündlichen Prüfung, 30, Juni, (1967).

12) N. Tsuchiya, S. Taguchi, Y. Takada and K. Okabe: Tetsuto-Hagané, 63 (1977), 1791.

13) E. T. Turkdogan: Metall. Trans. B, 9B (1978), 163. 